\title{
Comparison of proximal femoral nail and hemiarthroplasty outcomes in elderly (over 80 years old) patients with intertrochanteric fractures
}

\section{İntertrokanterik kırı̆̆ı olan ileri yaş (seksen yaş ve üstü) hastalarda, proksimal femoral çivi ve hemiartroplasti sonuçlarının karşılaştırılması}

\section{Ali Şişman ${ }^{1}$, Şevki Öner Şavk ${ }^{2}$, Serdar Kamil Çepni ${ }^{3}$}

\begin{abstract}
Aim: Proximal femoral nail (PFNA) and hemiarthroplasty are the two most frequently used methods in the surgical treatment of intertrochanteric femur fractures. The study aimed to determine the priority choice for surgical treatment in elderly patients (over 80 years old).

Methods: Patients treated for intertrochanteric femur fractures between 2012 and 2017 were retrospectively analyzed. Patients aged 80 years and over who were treated with hemiarthroplasty or PFNA were included in the study. The length of the operation, the need for postoperative intensive care, Harris Hip Score, postoperative complications, and mortality rates in the first year were compared.

Results: A total of 120 patients with intertrochanteric femur fractures older than 80 years were evaluated. There were 43 patients (35.8) in the hemiarthroplasty group and 77 (64.2) in the PFNA group. No significan differences were found between the two groups in terms of mortality, need for postoperative intensive care, Harris Hip Score, and postoperative complications in the first year. While the median operation time was 45 minutes (IQR 40-50) in the PFNA group, it was 80 minutes (IQR 75-85) in the hemiarthroplasty group (p $<0.001)$. The length of the operation was shorter in the PFNA group.

Conclusion: In elderly patients, there were no significant differences between the surgical treatment modalities as hemiarthroplasty and PFNA in treating intertrochanteric fractures considering the postoperative outcomes and mortality rates within the first year. However, shorter operation time might be an advantage of PFNA.
\end{abstract}

Keywords: Femoral intertrochanteric fracture, hemiarthroplasty, proximal femoral nail.

\section{Öz}

Amaç: İntertrokanterik femur kırığı olgularının cerrahi tedavisinde en sık kullanılan iki yöntem proksimal femoral çivi (PFNA) ve hemiartroplastidir. Çalışmanın amacı ileri yaştaki (80 yaş üzeri) olgularda öncelikl tedavi seçimini belirlemektir.

Yöntemler: 2012 -2017 yılları arasında yaşı 80 ve üzerinde olan intertrokanterik femur kırı̆̆ı nedeni ile hemiartroplasti ya da PFNA uygulanan hastalar retrospektif olarak incelendi. Ameliyat süreleri, ameliyat sonras yoğun bakım ihtiyacı, Harris Kalça Skoru, ameliyat sonrası komplikasyonlar ve ilk bir yıl içindeki ölüm oranlar karşılaștırıldı.

Bulgular: İntertrokanterik femur kırığı olan ve 80 yaşın üzerinde toplam 120 hasta değerlendirildi. Hastaların 43'ü $(35,8)$ hemiartroplasti grubunda, 77'si $(64,2)$ PFNA grubunda yer aldı. Her iki grup arasında ilk bir yıl içinde ölüm oranları, ameliyat sonrası yoğun bakım ihtiyacı, Harris Kalça Skoru ve ameliyat sonrası komplikasyonlar açısından anlamlı fark tespit edilmedi. Operasyon süresi PFNA grubunda medyan 45 dakika (çeyrekler arası açıklık 40-50) iken, hemiartroplasti grubunda medyan 80 dakika (çeyrekler arası açıklık 75-85) $(\mathrm{p}<0.001)$. Operasyon süresinin PFNA grubunda daha kısa olduğu görüldü.

Sonuç: İleri yaş olgularda, intertrokanterik kırık tedavisinde hemiartroplasti ve PFNA arasında ameliyat sonras sonuçlarda ve ilk bir yıl içindeki ölüm oranları arasında anlamlı fark bulunamamıştır. Buna rağmen ameliyat süresinin daha kısa olması PFNA'nın bir avantajı olarak değerlendirilebilir.

Anahtar Kelimeler: Femur intertrokanterik kırık, hemiartroplasti, proksimal femoral çivi.
Sultan 2. Abdulhamid Han Research and Education Hospital, Orthopedics and Traumatology Clinic, Istanbul, Turkey.

${ }^{2}$ Adnan Menderes University, Faculty of Medicine, Dept of Orthopedics and Traumatology, Aydin, Turkey.

Umraniye Research and Education Hospital, Orthopedics and Traumatology Clinic, Istanbul, Turkey.

\section{AS: 0000-0001-8461-3258}

SOS: 0000-0003-1647-7260

SKC: 0000-0002-6275-8250

Ethics Committee Approval: The study was approved by Adnan Menderes UniversityFaculty of MedicineEthical Committee of Clinical Studies (04.01.2018-2018-1294).

Etik Kurul Onayı: Bu çalışma Adnan Menderes Üniversitesi Tıp Fakültesi Klinik Çalışmalar Etik Kurulu'ndan onay almıştır (04.01.2018-2018/1294).

Conflict of Interest: No conflict of interest was declared by the authors.

Çıkar Çatışması: Yazar çıkar çatışması bildirmemiştir.

Financial Disclosure: The authors declared that this study has received no financial support.

Finansal Destek: Yazarlar bu çalıșma için finansal destek almadıklarını beyan etmişlerdir.

Geliş Tarihi / Received: 27.09.2020

Kabul Tarihi / Accepted: 12.03.2021

Yayın Tarihi / Published: 01.04.2021

Sorumlu yazar / Corresponding author:

Ali Şişman

Adres/Address: Sultan 2. Abdulhamid Han Eğitim ve Araştırma Hastanesi Ortopedi ve Travmatoloji Kliniği, Selimiye, Tıbbiye Cad, 34668, Üsküdar, İstanbul, Türkiye.

e-mail: ali_sisko@hotmail.com

Tel/Phone: +905068800262

Copyright (C) ACEM 


\section{Introduction}

Intertrochanteric fractures are the common clinical situations in the elderly population and are mainly associated with osteoporosis. These fractures cause severe morbidity and mortality [1]. In the treatment of trochanteric fractures, there is a consensus on surgical treatment choices that allow early mobilization and restore function to the extremity to prevent complications and reduce the mortality rates $[2,3]$.

Although there are different treatment options, intramedullary nails are among the most frequently used methods due to the high blood supply potential of the region, their biomechanical advantage, and their easy application with minimally invasive techniques $[4,5]$. However, complications and poor functional results, especially in osteoporotic patients due to intramedullary fixation methods, have recently increased the popularity of hemiarthroplasty applications. The advantage of hemiarthroplasty has been reported as enabling mobilization with full load early and eliminating healing problems due to fracture [6]. Also, complications due to the longer duration of the operation with hemiarthroplasty and increased postoperative mortality in elderly patients appeared as disadvantages $[6,7]$.

For these reasons, there is no consensus on which method is superior in the surgical treatment of intertrochanteric fractures, especially in elderly patients with poor bone quality. Our study's hypothesis was to show the proximal femoral nail (PFNA) choice is superior considering the mortality in patients with intertrochanteric femur fractures in the advanced age. Accordingly, we aimed to compare the literature by comparing which of the hemiarthroplasty and PFNA choices is superior in patients with intertrochanteric femur fractures over 80 years old.

\section{Material and methods}

\section{Study design and study criteria}

At the beginning of the study, we took approval from Adnan Menderes University, Faculty of Medicine, Clinical Research Ethics Committee (Date: January $4^{\text {th }}$, 2018, Number: 2018/1294). The study was performed in accordance with the Declaration of Helsinki. Written consent could not be taken due to the retrospective design of the study and unanimity of data.

The cases treated in our clinic due to intertrochanteric femur fracture between 2012 and 2017 were retrospectively analyzed using the hospital information system and the picture archiving systems. Patients over 80 years of age who underwent hemiarthroplasty or PFNA due to intertrochanteric fractures were included in the study. Patients who underwent conservative treatment, fixed with plate screws in surgical treatment, lost follow-up or whose follow-up period was less than one year, and patients whose archive records could not reach sufficient information were excluded from the study. Following the inclusion and exclusion criteria, the patients were divided into two groups: those who underwent hemiarthroplasty (Zimmer, Inc, Warsaw, IN) and PFNA (Synthes ${ }^{\circledR}$ Oberdorf, Switzerland). Surgery was performed using the same brand of implant in accordance with the group in which all patients were included.

A total of 143 patients with advanced age and intertrochanteric fractures were evaluated. Of them, 23 of the cases were not included in the study. Of the 120 patients included in the study, 43 (35.8) were in the hemiarthroplasty group, and 77 (64,2) were in the PFNA group.

Standard anteroposterior hip radiographs and pelvic radiographs were obtained for all patients included in the study. Unless contraindicated, all patients received thromboembolism prophylaxis with subcutaneous anticoagulant therapy from the first day of hospitalization to the first month after the surgery. Mechanical prophylaxis was applied with embolism stockings. All patients were administered a single dose of 1 gram cephalosporin 30 minutes before the surgery. In the case of prolonged surgery, an additional dose of cephalosporin was administered after the second hour.

In-bed exercise was started for the patients in both groups the day after the surgery. The patient group, who was applied PFNA, was raised with a walker in the early period without any load. At the earliest first month after the radiography control, the callus was seen, and mobilization with full load was allowed. Hemiarthroplasty patients were raised with full load bearing in the first period when their general condition was available.

\section{Surgical techniques}

All cases were operated by the same surgeon, in the same operating room, and using the same fluoroscopy device. Fractures were evaluated according to the Evans-Jensen classification. None of the fractures included in the study were reverse oblique according to the Evans-Jensen classification. The fractures included in the study were not subclassified. Regardless of the fracture classification, firstly, closed reduction was tried in all cases on the traction table. After being taken to the traction table, abduction, external rotation, adduction, and internal rotation maneuvers were performed on all fractures for reduction purposes. A suitable position was provided for reduction, and anteroposterior and lateral fluoroscopy images were obtained. While evaluating the reduction, the continuity of the posteromedial cortex was checked. The patient was stained and covered with the reduction appreciated, and PFNA was applied (Figure 1). Patients with successful reduction formed the PFNA group. In cases where reduction was not appropriate, the cases were placed in the lateral decubitus position, and hemiarthroplasty was performed with a posterior approach (Figure 2). The patients whose reduction failed constituted the hemiarthroplasty group. Hemiarthroplasty was applied to all patients for whom arthroplasty was preferred, and total hip arthroplasty was not applied to any patient.

Operation duration, postoperative intensive care need, postoperative complications, mortality rates within the first year, and Harris Hip Score at the 12 months after the surgery were compared.

\section{Statistical analysis}

SPSS 21.0 statistics program was used in our study. Whether the quantitative variables were suitable for normal distribution was examined by the Kolmogorov-Smirnov test. Groups were compared using the independent-samples t-test for variables with normal distribution and the Mann Whitney U test for variables that did not show normal distribution. Descriptive statistics of normally distributed quantitative variables were shown as mean \pm standard deviation, and descriptive statistics of non-normally distributed quantitative variables were shown as median (interquartile range (IQR) $25-75^{\text {th }}$ percentile). The dependence between qualitative variables was examined using chi-square analysis. Descriptive statistics of these variables were 
expressed as frequency $(\%)$. A $\mathrm{p}<0.05$ value was considered statistically significant.

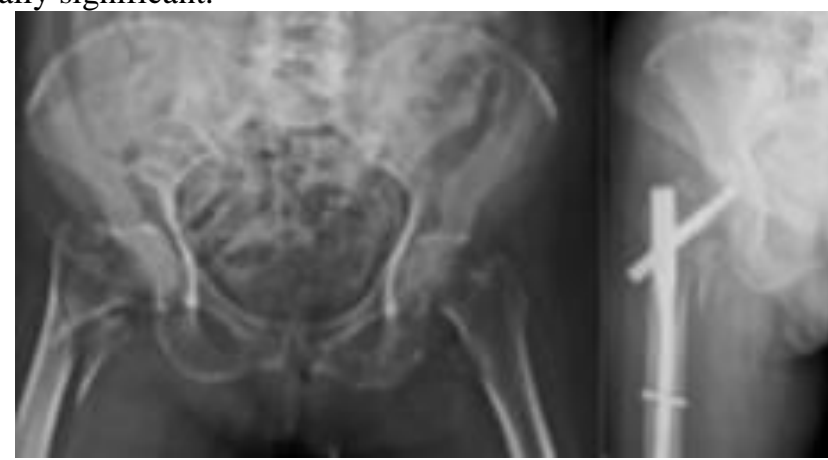

Figure 1. Pre-operative and postoperative first-year radiographs of an 83-year-old patient who underwent PFNA.

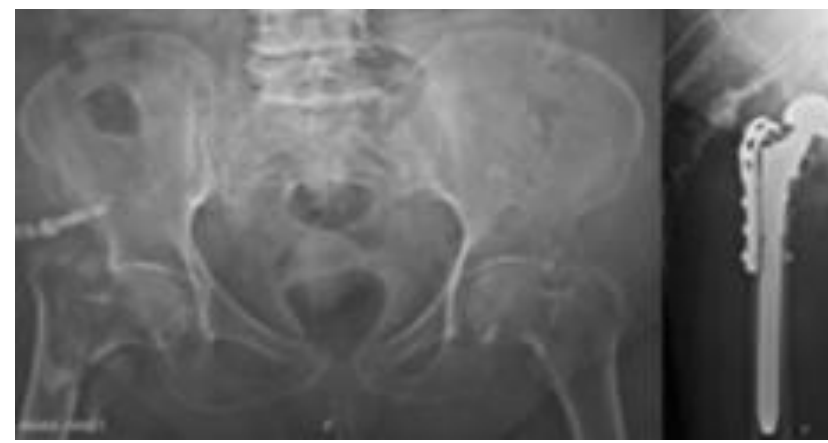

Figure 2. Pre-operative and postoperative radiographs of an 83-year-old patient who underwent hemiarthroplasty.

\section{Results}

The median age of those who underwent hemiarthroplasty was 85 years (range $81-86$ ), and the median age of those who received PFNA was 83 years (IQR 81-86). The gender distribution between the groups was homogeneous. 48 $(62.3 \%)$ of 77 patients who were applied PFNA were female, and $29(37.7 \%)$ were male. Of the 43 patients who underwent hemiarthroplasty, $29(67.4 \%)$ were female and 14 (32.6\%) were male $(p=0.718)$. While the median operation time was 45 minutes (IQR 40-50) in the PFNA group, it was 80 minutes (IQR $75-85)$ in the hemiarthroplasty group $(p<0.001)$. Postoperative intensive care need was $58.4 \%$ (45 cases) in the PFNA group and $79.1 \%$ (34 cases) in the hemiarthroplasty group $(p=0.037)$. The Harris Hip Score was evaluated at 12 months postoperatively. The mean score was $60.5 \pm 18.9$ in the PFNA group, and the mean score was $53.52 \pm 16.11$ in the hemiarthroplasty group. The median duration of the follow-up was 48 months (IQR 25-65) in the PFNA group and 36 months (IQR 25-61) in the hemiarthroplasty group $(\mathrm{p}=0.186)$. While the mortality rate in the first year was $35.1 \%$ (27 cases) in the PFNA group, it was found to be $41.9 \%$ (18 cases) in the hemiarthroplasty group $(\mathrm{p}=0.589)$ (Table 1).

In our study, heterotopic ossification in three (7\%), wound infection in two $(4.7 \%)$, prosthesis infection in one $(2.3 \%)$, and dislocation in one $(2.3 \%)$ occurred in patients who underwent hemiarthroplasty. Wound infection in three $(3.9 \%)$, implant failure in two $(2.6 \%)$, cut-out in two $(2.6 \%)$, nonunion in one $(1.3 \%)$, and periprosthetic fracture in one $(1.3 \%)$ occurred in the PFNA group (Table 2).

\section{Discussion}

In our study, PFNA and hemiarthroplasty outcomes were compared in elderly patients with intertrochanteric femur fractures, and similar results were obtained. The significantly shorter operative time was regarded as an advantage of PFNA

The ideal treatment method for intertrochanteric fractures continues to be debated. In treating intramedullary nails, which is the most common treatment method, failures, especially in elderly patients, have recently made the hemiarthroplasty option popular [8]. Problems such as loss of fixation, loss of reduction, and malunion increase the concerns of failure, especially in patients over 80 years of age with poor bone quality [5, 9]. Postoperative complications decrease with the early mobilization of elderly patients. It has made hemiarthroplasty an alternative in the treatment of intertrochanteric fractures with its early full-load mobilization advantage $[10,11]$.

Table 1. Comparison of demographic information, general results, surgical data and postoperative results between groups.

\begin{tabular}{|c|c|c|c|}
\hline Variables & $\begin{array}{l}\text { PFNA Group } \\
\quad(\mathrm{n}=77)\end{array}$ & $\begin{array}{l}\text { Hemiarthroplasty } \\
\text { Group }(n=43)\end{array}$ & $\mathrm{p}$ \\
\hline Age $(\text { year })^{\dagger}$ & $83(81-86)$ & $85(83-88)$ & 0.034 \\
\hline Gender ${ }^{\ddagger}$ & & & 0.718 \\
\hline Male & $29(37.7)$ & $14(32.6)$ & \\
\hline Female & $48(62.3)$ & $29(67.4)$ & \\
\hline $\begin{array}{l}\text { The median duration of } \\
\text { follow-up (day) }{ }^{\dagger}\end{array}$ & $48(25-65)$ & $36(25-61)$ & 0.186 \\
\hline Operation duration (minute) ${ }^{\dagger}$ & $45(40-50)$ & $80(75-85)$ & $<0.001$ \\
\hline Need for intensive care unit & $45(58.4)$ & $34(79.1)$ & 0.037 \\
\hline Mean death time (days) ${ }^{\dagger}$ & $88(35-291)$ & $41.5(18-142)$ & 0.123 \\
\hline Mortality in the first year & $27(35.1)$ & $18(41.9)$ & 0.589 \\
\hline Harris Hip Score ${ }^{¥}$ & $60.5 \pm 18.96$ & $53.52 \pm 16.11$ & 0.118 \\
\hline
\end{tabular}


The most important advantage of PFNA is that it reduces surgery-related complications due to its short operation duration. In the study of Parker et al. [12], PFNA operation duration was 36 minutes, while hemiarthroplasty operation duration was 57 minutes. Also, the operation duration of PFNA was found to be shorter than hemiarthroplasty in many other studies [13-15]. Similar to the literature, the operation time of the PFNA group was shorter in our study. The average operation duration in patients with PFNA was 45 minutes, while it was 80 minutes in the hemiarthroplasty group. Intramedullary nailing significantly shortened the operation duration that is regarded as an advantage.

Studies are claiming higher mortality rates after hemiarthroplasty compared to PFNA in the surgical treatment of intertrochanteric fractures. Nie et al. [13] reported that the first year's mortality rate in patients who underwent hemiarthroplasty was higher than those with PFNA. Some studies did not find a significant difference in mortality rates within the first year [12, 16]. In the study of Kumar et al. [17] and other similar studies $[18,19]$, patients with advanced age were evaluated as in our study, and no significant difference was found between the two groups in terms of mortality in the first year. In our study, the mean day of death in the PFNA group was 88 days, whereas it was 41.5 days in the hemiarthroplasty group (not given in the text). Although there was an earlier death in the hemiarthroplasty group, no statistically significant difference was found.

\begin{tabular}{|c|c|c|c|}
\hline Complications ${ }^{\ddagger}$ & $\begin{array}{l}\text { PFNA } \\
\text { Group } \\
(n=77)\end{array}$ & $\begin{array}{l}\text { Hemiarthroplasty } \\
\text { Group }(n=43)\end{array}$ & $\mathrm{p}$ \\
\hline $\begin{array}{l}\text { Heterotopic } \\
\text { ossification }\end{array}$ & - & $3(7)$ & \\
\hline Wound infection & $3(3.9)$ & $2(4.7)$ & \\
\hline $\begin{array}{l}\text { Prosthesis } \\
\text { infection }\end{array}$ & - & $1(2.3)$ & 0.076 \\
\hline Dislocation & - & $1(2.3)$ & \\
\hline İmplant failure & $2(2.6)$ & - & \\
\hline Cut-out & $2(2.6)$ & - & \\
\hline Non-union & $1(1.3)$ & - & \\
\hline $\begin{array}{l}\text { Periprosthetic } \\
\text { fracture }\end{array}$ & $1(1.3)$ & - & \\
\hline
\end{tabular}

The prolongation of the operation duration and the deterioration of hemodynamics due to bleeding cause an increased need for postoperative intensive care. According to the studies performed, blood loss and blood transfusion need are higher with hemiarthroplasty [17, 19]. In our study, when the ratio of patients who needed postoperative intensive care was examined, no significant difference was found between the two groups.

Görmeli et al. [20] found the Harris Hip Score of 74.7 in the hemiarthroplasty group and 79.7 in the PFNA group. Li et al. [21] reported a Harris Hip Score of 85.6 in patients with intertrochanteric fractures to which they applied PFNA. In their study published in 2017, Hari Prasad et al. [22] found that the Harris Hip Score was higher in patients who underwent hemiarthroplasty. They recommended hemiarthroplasty for the treatment of intertrochanteric fractures. There was no significant difference between the two groups in the 12-month evaluation of Harris Hip Score in our study.

This study has several limitations. The main limitations were retrospective study, small sample size, and not including subgroups in the classification. Besides, since the follow-up periods in elderly patients were short, long-term analyzes could not be included. Besides, performing all operations by the same surgeon, using the same implants, performing operations with the same operating room and fluoroscopy device were the advantages of this study.

In conclusion, there was no significant difference between the two groups in terms of mortality in the first year, need for postoperative intensive care, 12-month Harris Hip scores, and postoperative complications. Due to the shorter operation time in the PFNA group, it is seen as an advantage in patients' surgical treatment with intertrochanteric fractures over 80 years old.

\section{References}

1. Guzon-Illescas O, Perez Fernandez E, Crespí Villarias N, Quirós Donate FJ, Peña M, Alonso-Blas $\mathrm{C}$, et al. Mortality after osteoporotic hip fracture: incidence, trends, and associated factors. J Orthop Surg Res. 2019;14:203.

2. Haentjens P, Casteleyn PP, De Boeck H, Handelberg F, Opdecam P. Treatment of unstable intertrochanteric and subtrochanteric fractures in elderly patients. Primary bipolar arthroplasty compared with internal fixation. J Bone Joint Surg Am. 1989;71:1214-25.

3. Kesmezacar H, Oğüt T, Bilgili MG, Gökay S, Tenekecioğlu Y. [Treatment of intertrochanteric femur fractures in elderly patients: internal fixation or hemiarthroplasty]. Acta Orthop Traumatol Turc. 2005;39:287-94.

4. Sambandam SN, Chandrasekharan J, Mounasamy V, Mauffrey C. Intertrochanteric fractures: a review of fixation methods. Eur J Orthop Surg Traumatol. 2016;26:339-53.

5. Socci AR, Casemyr NE, Leslie MP, Baumgaertner MR. Implant options for the treatment of intertrochanteric fractures of the hip: rationale, evidence, and recommendations. Bone Joint J. 2017;99-B:128-33.

6. Fichman SG, Mäkinen TJ, Safir O, Vincent A, Lozano B, Kashigar A, et al. arthroplasty for unstable pertrochanteric hip fractures may offer a lower re-operation rate as compared to cephalomedullary nailing. Int Orthop. 2016;40:15-20.

7. Kim SY, Kim YG, Hwang JK. Cementless calcar-replacement hemiarthroplasty compared with intramedullary fixation of unstable intertrochanteric fractures. A prospective, randomized study. J Bone Joint Surg Am. 2005;87:2186-92.

8. Green S, Moore T, Proano F. Bipolar Prosthetic Replacement for the Management of Unstable Intertrochanteric Hip Fractures in the Elderly. Clin Orthop Relat Res. 1987;224:169-77.

9. Kumar Gn K, Meena S, Kumar N V, S M, Raj Mk V. Bipolar hemiarthroplasty in unstable intertrochanteric fractures in elderly: a prospective study. J Clin Diagn Res. 2013;7:1669-71.

10. Kayali C, Agus H, Ozluk S, Sanli C. Treatment for unstable intertrochanteric fractures in elderly patients: internal fixation versus cone hemiarthroplasty. J Orthop Surg. 2006;14:240-4.

11. Fahad S, Nawaz Khan MZ, Khattak MJ, Umer M, Hashmi P. Primary Proximal femur replacement for unstable osteoporotic intertrochanteric and subtrochanteric fractures in the elderly: A retrospective case series. Ann West Med Surg. 2019;44:94-7.

12. Parker MJ, Khan RJK, Crawford J, Pryor GA. Hemiarthroplasty versus internal fixation for displaced intracapsular hip fractures in the elderly. A randomised trial of 455 patients. J Bone Joint Surg Br. 2002;84:1150-5.

13. Nie B, Wu D, Yang Z, Liu Q. Comparison of intramedullary fixation and arthroplasty for the treatment of intertrochanteric hip fractures in the elderly: A meta-analysis. Medicine. 2017;96:e7446.

14. Yoo JI, Ha YC, Lim JY, Kang H, Yoon BH, Kim H. Early Rehabilitation in Elderly after Arthroplasty versus Internal Fixation for Unstable Intertrochanteric Fractures of Femur: Systematic Review and Meta-Analysis. J Korean Med Sci. 2017;32:858. 
15. Esen E, Dur H, Ataoğlu MB, Ayanoğlu T, Turanlı S. Evaluation of proximal femoral nail-antirotation and cemented, bipolar hemiarthroplasty with calcar replacement in treatment of intertrochanteric femoral fractures in terms of mortality and morbidity ratios. Eklem Hastalik Cerrahisi. 2017;28:35-40.

16. Luo X, He S, Zeng D, Lin L, Li Q. Proximal femoral nail antirotation versus hemiarthroplasty in the treatment of senile intertrochanteric fractures: Case report. Int J Surg Case Rep. 2017;38:37-42.

17. Kumar P, Rajnish RK, Sharma S, Dhillon MS. Proximal femoral nailing is superior to hemiarthroplasty in AO/OTA A2 and A3 intertrochanteric femur fractures in the elderly: a systematic literature review and meta-analysis. Int Orthop. 2020;44:62333.

18. Huang J, Shi Y, Pan W, Wang Z, Dong Y, Bai Y, et al. Bipolar Hemiarthroplasty should not be selected as the primary option for intertrochanteric fractures in elderly patients. Sci Rep. 2020;10:4840.

19. Tan WL, Shi YX, Zhang JY, Tang CR, Guan QB, Tan JJ. Bipolar Hemiarthroplasty should not be selected as the primary option for intertrochanteric fractures in elderly patients aged 85 years or more. Medicine. 2020;99:e21862.

20. Görmeli G, Gözükara H, Görmeli C, Karakaplan M, Korkmaz M, Diliçıkık U. Outcome of transtibial AperFix system in anterior cruciate ligament injuries. Indian $\mathrm{J}$ Orthop. 2015;49:150.

21. Li M, Wu L, Liu Y, Wang C. Clinical evaluation of the Asian proximal femur intramedullary nail antirotation system (PFNAII) for treatment of intertrochanteric fractures. J Orthop Surg Res. 2014;9:139.

22. Prasad S H, Patil SN, Chandra P S, Fernando A C. Functional outcome of unstable intertrochanteric femur fracture in elderly osteoporotic patients treated by primary cemented bipolar hemiarthroplasty versus internal fixation with proximal femoral nailing. Int J Orthop Sci. 2017;3:321-5. 